\title{
Melon Rugose Mosaic Virus: Characterization of an Isolate from Sudan and Seed Transmission in Melon
}

\author{
Hanan A. Mahgoub, Catherine Wipf-Scheibel, and Brigitte Delécolle, INRA, Station de Pathologie Végétale, \\ B.P. 94, 84143 Montfavet Cedex, France; Michel Pitrat, INRA, Station d'Amélioration des Plantes Maraîchères, \\ B.P. 94, 84143 Montfavet Cedex, France; Gasim Dafalla, Plant Pathology Centre, University of the Gezira, Wad \\ Medani, Sudan; and Hervé Lecoq, INRA, Station de Pathologie Végétale, B.P. 94, 84143 Montfavet Cedex, France
}

\begin{abstract}
Mahgoub, H. A., Wipf-Scheibel, C., Delécolle, B., Pitrat, M., Dafalla, G., and Lecoq, H. 1997. Melon rugose mosaic virus: Characterization of an isolate from Sudan and seed transmission in melon. Plant Dis. 81:656-660.

Melon rugose mosaic virus (MRMV) was isolated from snake cucumber (Cucumis melo var. flexuosus) in the Kassala region of Sudan in 1993. The host range of the virus was mostly limited to cucurbits, where it induced severe mosaic and leaf deformations. Cytopathological studies revealed severe chloroplast alterations, including vesicles at their periphery and the tendency to aggregate, which are typical of tymovirus infections, providing further evidence that MRMV is a tentative member of the genus Tymovirus. In melon and snake cucumber, MRMV was found to be seed transmitted at rates of 0.9 and $3.8 \%$, respectively. Seed dissection experiments revealed that the virus could be detected in the seed coat, papery layer, and embryo. Seed disinfection treatments did not reduce seed transmission rates, which suggests an internal transmission. A preliminary screening for resistance in melon revealed some resistance in two out of 367 accessions tested.
\end{abstract}

Melon rugose mosaic virus (MRMV) was first reported in Yemen by Jones et al. in 1986 (9). This virus caused severe mosaic symptoms in melon (Cucumis melo L.), snake cucumber (C. melo var. flexuosus Naud.), and watermelon (Citrullus lanatus (Thunb.) Matsum. \& Nakai) in the former People's Democratic Republic of Yemen and Yemen Arab Republic (1,10). Based on morphology and on the biophysical and biochemical properties of the virions, MRMV was related to tymoviruses (9).

Cucurbit viruses are very important in Sudan, where they can completely destroy melon, snake cucumber, watermelon, and squash crops. A preliminary survey conducted in various growing regions of Sudan (14) revealed the frequent occurrence of cucurbit aphid-borne yellows luteovirus (CABYV), zucchini yellow mosaic potyvirus (ZYMV), watermelon chlorotic stunt geminivirus (WCSV), and squash mosaic comovirus (SqMV). In addition, MRMV was detected in snake cucumbers collected in the Kassala region of Eastern Sudan, presenting severe mosaic and leaf deformation symptoms (14).

This paper reports elements for the characterization of an isolate of MRMV from

Corresponding author: H. Lecoq
E-mail: cornic@avignon.inra.fr

Accepted for publication 6 March 1997.

Publication no. D-1997-0423-09R

(C) 1997 The American Phytopathological Society
Sudan. Seed transmission in melons was demonstrated, and a preliminary screening for resistance in a melon germ plasm collection was conducted.

\section{MATERIALS AND METHODS}

Virus isolate and host range study. The virus isolate used during the course of this study was obtained from a naturally infected snake cucumber ( $C$. melo var. flexuosus) plant collected near Kassala, Sudan. This plant showed severe symptoms of mosaic and blisters on intermediate leaves, while young leaves exhibited milder symptoms. This plant was found by double antibody sandwich enzyme-linked immunosorbent assay (DAS-ELISA) to be devoid of other viruses, including ZYMV, CABYV, WCSV, SqMV, cucumber mosaic cucumovirus (CMV), and papaya ringspot type $\mathrm{W}$ potyvirus (PRSV-W).

Leaves from infected plants were triturated with $0.03 \mathrm{M} \mathrm{Na}_{2} \mathrm{HPO}_{4}$ containing $0.2 \%$ Na-diethyldithiocarbamate (DIECA) $(1: 10 ; \mathrm{wt} / \mathrm{vol})$ with a mortar and pestle. Extracted juice was mixed with 400-mesh Carborundum $(75 \mathrm{mg} / \mathrm{ml})$ and activated charcoal $(75 \mathrm{mg} / \mathrm{ml})$ before being rub-inoculated on test plants. The susceptibility of 30 plant species belonging to 10 botanical families was tested following mechanical inoculation of groups of three plants for each species. The presence of the virus in the inoculated leaves and the plant apex was tested 2 weeks after inoculation by DAS-ELISA and 7 to 10 days later, in the plant apex only. The test was performed three times.
Virus purification and antiserum production. MRMV was purified using a method combining extraction with Freon 113 (1,1,2-trifluoro-1,2,2-trichloroethane), one cycle of differential centrifugation, and equilibrium density gradient centrifugation in $\mathrm{Cs}_{2} \mathrm{SO}_{4}$ (15). The final virus concentration was determined spectrophotometrically by using an extinction coefficient of 9.6 (18).

A viral suspension of $2 \mathrm{mg} / \mathrm{ml}$ was emulsified with an equal volume of Freund's complete adjuvant and injected intramuscularly into the hind legs of a rabbit. Five similar injections were made at 2week intervals, except that the complete adjuvant was replaced by incomplete adjuvant. Bleedings were started after the second injection.

Serological tests. Immunodiffusion tests were conducted with $0.75 \%$ agarose gels containing $0.85 \%$ sodium chloride and $0.02 \%$ sodium azide in $0.1 \mathrm{M}$ phosphate buffer, $\mathrm{pH} 7.2$ (9).

IgGs and alkaline phosphatase conjugated IgGs were prepared according to standard procedures and used for DASELISA (5). Samples were ground in the inoculation buffer at 1:10 (wt/vol). In preliminary tests, well-to-well contaminations were observed in DAS-ELISA, probably due to the high virus concentration in plant extracts. Subsequently, a special care was taken to prevent contaminations during sample preparation, and in microtiter plates for DAS-ELISA, a buffer-only column was included between two columns with samples. Under these conditions, contaminations were not observed.

Electron microscopy. Crude extracts or diluted purified virus preparations were observed with a Philips CM10 (Eindhoven, The Netherlands) electron microscope using pyroxilin-coated grids and $1 \%$ ammonium molybdate, $\mathrm{pH} 7$, as a negative stain. Virus particles were measured using a carbon replica calibrated at $463 \mathrm{~nm}$ as a reference.

For cytopathological studies, leaf pieces $1 \mathrm{~mm}$ across were collected on the older, intermediate, and younger leaves from infected melon plants 2 weeks after inoculation, and from younger leaves only, 2 months after inoculation. Similar samples from healthy plants were used as controls. Samples were fixed with glutaraldehyde, postfixed with osmium tetroxide, and em- 
bedded in araldite CY212 (Agar Scientific Ltd., Stansted, UK) (6). Thin sections were cut with a diamond knife using an Ultracut E (Reichert-Jung, Wien, Austria) ultramicrotome. Thin sections were stained in 5\% uranyl acetate and lead citrate, $\mathrm{pH} 12$, before observations.

Seed transmission experiments. Melon plants (two Charentais type cultivars, Védrantais and Doublon, and a snake cucumber local type from Sudan) were mechanically inoculated at the two- to threeleaf stage, transplanted 2 weeks later into larger pots, and kept under insect-proof conditions with regular fertilization and pesticide applications. Plants were selfed by hand pollination, and fruits were collected at maturity. Seeds were extracted using maceration for $24 \mathrm{~h}$ in a solution containing a pectinase enzyme (Rapidase Excolor, Gist Brocades, France) at 0.3 $\mathrm{g} / \mathrm{liter}$ and $\mathrm{HCl}(6.7 \mathrm{ml} / \mathrm{liter}$ of a $33 \%$ solution), then rinsed three to four times in tap water and dried at room temperature.

Seedlings were raised from different seed lots, and the presence of the virus was first determined by visual assessment and confirmed by DAS-ELISA. Once seed transmission was established, snake cucumber seed lots with the highest transmission rates were pooled for further experiments.

Two seed disinfection protocols were used to tentatively eliminate seed coat contaminations on snake cucumber seeds. One used $\mathrm{HCl} 0.1 \mathrm{~N}$ (4), while the other used a solution containing $10 \% \quad \mathrm{Na}_{3} \mathrm{PO}_{4}$, $0.5 \%$ sodium dodecyl sulfate (SDS), $0.5 \%$ Tween 20, and 2\% sodium hypochlorite, efficient to remove pepper mild mottle tobamovirus contamination from pepper seeds (K. Gebré Sélassié, personal communication). Seeds were immersed in the disinfectant and kept under slight shaking for $30 \mathrm{~min}$ before being washed for $30 \mathrm{~min}$ under running tap water and left to dry.

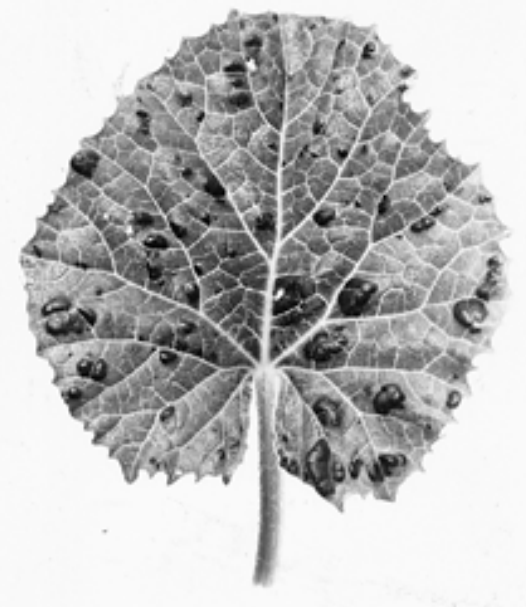

Fig. 1. Mosaic and blisters caused by melon rugose mosaic virus (MRMV) in Cucumis melo 'Védrantais'.
Nontreated seeds from the same seed lots were used as a control.

Seed dissections were conducted according to Nolan and Campbell (19) to determine the location of the virus in the seeds. Twenty seeds from each treatment were dissected, and the seed coats, papery layers, and embryos were separately subjected to further disinfection using $10 \%$ $\mathrm{Na}_{3} \mathrm{PO}_{4}$ for $10 \mathrm{~min}$ before being washed with distilled water once, followed by four washes with the inoculation buffer. Each individual seed part was then ground in 0.5 $\mathrm{ml}$ of inoculation buffer; $0.3 \mathrm{ml}$ of the extract was used for DAS-ELISA, and the rest was used for inoculating melon seedlings at the cotyledonary stage.

Screening for resistance. Three hundred sixty-seven melon lines of different geographical origins and fruit types were mechanically inoculated and assessed twice for systemic infection by visual observation and by DAS-ELISA. The complete list of the tested accessions can be obtained from the authors. All of these accessions were increased by selfing.

\section{RESULTS}

Characterization of MRMV. MRMV was detected in a snake cucumber sample from Kassala by a positive reaction in DAS-ELISA with an antiserum produced against the type strain from Yemen, kindly provided by P. Jones (9). Following mechanical inoculation, melon cv. Védrantais developed severe mosaic and dark green blisters (Fig. 1) similar to those described for MRMV $(9,20)$. Numerous isometric virus particles were observed in leaf extracts from the original infected plant, or from mechanically inoculated plants, some of which appeared as "empty" particles (Fig. 2A).

The virus was purified from infected melons, with a final yield of $0.5 \mathrm{~g} / \mathrm{kg}$. Purified preparations observed after negative staining contained isometric particles ca. $31 \mathrm{~nm}$ in diameter (estimate derived from the measurement of 100 particles), few of which also appeared as empty particles (Fig. 2B). In immunodiffusion tests, extracts from a dry culture of the Yemen isolate and from the Sudan isolate reacted with the two homologous antisera by forming precipitation lines that fused, confirming the close serological relationship (if not identity) between the two isolates. Unfortunately, the Yemen culture could not be reactivated, and further comparisons between these isolates could not be conducted.

IgGs and the alkaline phosphatase-conjugated $\mathrm{IgGs}$ at a concentration of $1 \mathrm{mg} / \mathrm{ml}$ could be used at a dilution up to $1 / 16,000$ in DAS-ELISA. In standard tests, infected leaf samples diluted 1:10 gave absorbance readings at $405 \mathrm{~nm}$ in the range of 1.5 to 2 within $30 \mathrm{~min}$, while healthy controls had readings of 0.00 to 0.02 .

Following mechanical inoculation of MRMV, systemic symptoms were observed only in some cucurbits, including watermelon, snake cucumber, melon, and cucumber (Cucumis sativus L.), but not in squash (Cucurbita pepo L. and Cucurbita moschata (Duchesne) Duchesne ex Poir.). None of the 25 plant species outside the cucurbits developed systemic symptoms (Table 1). DAS-ELISA confirmed systemic infections in symptomatic plants. They also revealed local infections in squashes and in some noncucurbit hosts. However, in some cases, DAS-ELISA readings in inoculated leaves of noncucurbits were irregular and very low (Table 1). It is not known whether this detected antigen remains from the inoculum or indicated subliminal infections.

Cytopathology. In mesophyll cells of healthy plants, chloroplasts were lensshaped in section, bordered by a regular double membrane which showed no invaginations or vesicles (Fig. 3A). In young leaves from plants inoculated with MRMV 2 weeks earlier, peripheral vesiculations were observed on a few chloroplasts,

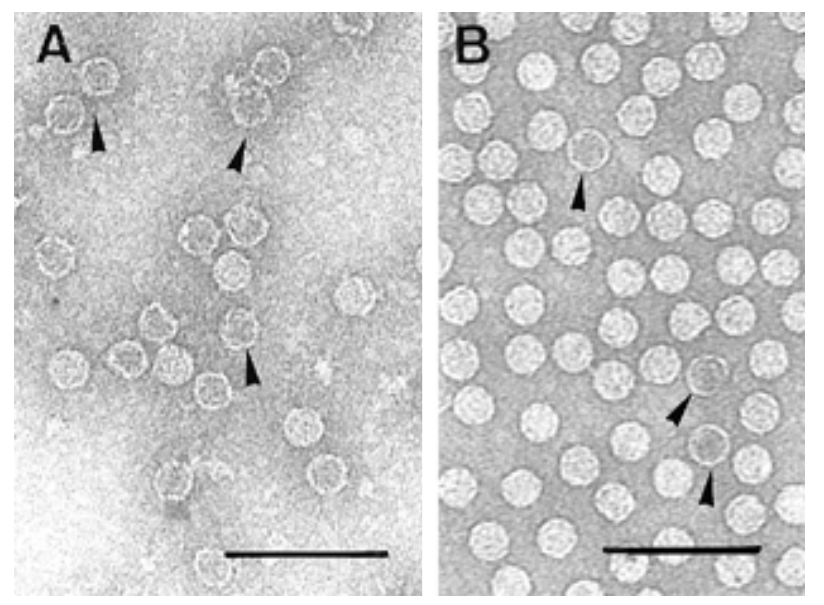

Fig. 2. Melon rugose mosaic virus particles observed after negative staining using ammonium molybdate (A) in crude extracts of an infected melon leaf and (B) in a purified preparation. Arrows indicate "empty" particles. Scale bars represent $100 \mathrm{~nm}$. 
which had a swollen shape (Fig. 3B), and few virion aggregates were observed. In intermediate leaves, these disorders were more common, chloroplasts were clumped (Fig. 3C), and a large density of peroxisomes was observed next to the chloroplasts (Fig. 3D). In older leaves, the chloroplast periphery was very vesiculated, and chloroplasts were aggregated, forming virions pockets surrounded by a doublemembrane (Fig. 3E). Alterations were also observed in the nucleus, with large amounts of electron-lucent material and chromatin mostly located at the nucleus periphery (Fig. 3F). No viruslike particles were observed inside the nucleus.
In plants with 2-month-old infections, similar alterations were observed in young leaves, but many more virus aggregates were observed in the cytoplasm and vacuoles of parenchyma cells (Fig. 3G). Large accumulations of empty particles in crystalline arrays were detected in non-fully differentiated xylem tubes, with a few electron-dense complete nucleoproteins (Fig. 3H).

Seed transmission. Seventy-three fruits from infected melons of Charentais type and of snake cucumber type were collected. At least 30 seeds from each seed lot were sown. MRMV seed transmission was observed in 20 out of the 73 seed lots

Table 1. Reaction of a differential host range to melon rugose mosaic virus

\begin{tabular}{|c|c|c|}
\hline Differential hosts & Symptoms L/S ${ }^{a}$ & DAS-ELISA ${ }^{\mathrm{b}} \mathbf{L} / \mathbf{S}$ \\
\hline \multicolumn{3}{|l|}{ Asteraceae } \\
\hline Cichorium endivia $\mathrm{L}$. & $0 / 0^{c}$ & $-/-^{d}$ \\
\hline Lactuca sativa $\mathrm{L}$. & $0 / 0$ & $(+) /-$ \\
\hline \multicolumn{3}{|l|}{ Brassicaceae } \\
\hline Brassica napus (L.) Metzger & $0 / 0$ & $-1-$ \\
\hline \multicolumn{3}{|l|}{ Chenopodiaceae } \\
\hline Chenopodium amaranticolor Coste \& Reyn. & $0 / 0$ & $++/-$ \\
\hline C. quinoa Willd. & $0 / 0$ & $(+) /-$ \\
\hline \multicolumn{3}{|l|}{ Cucurbitaceae } \\
\hline $\begin{array}{l}\text { Citrullus lanatus (Thunb.) Matsum. \& Nakai } \\
\text { 'Sugar Baby' }\end{array}$ & $0 / \mathrm{M}$ & $+++/+++$ \\
\hline Cucumis melo L. 'Védrantais' & 0/M,B & +++/+++ \\
\hline C. melo var. agrestis & $0 / \mathrm{M}, \mathrm{Y}$ & $+++/+++$ \\
\hline C. melo var. flexuosus & nll/M,B & +++/+++ \\
\hline C. sativus L. 'Marketer' & $0 / \mathrm{VC}$ & +++/+++ \\
\hline $\begin{array}{l}\text { Cucurbita moschata (Duchesne) Duchesne } \\
\text { ex Poir. 'Musquée de Provence'' }\end{array}$ & $0 / 0$ & $+++/-$ \\
\hline Cucurbita pepo L. 'Diamant' & $0 / 0$ & $+++/-$ \\
\hline C. pepo 'Eskandrani' & $0 / 0$ & $+++/-$ \\
\hline \multicolumn{3}{|l|}{ Fabaceae } \\
\hline Phaseolus vulgaris L. & $0 / 0$ & $-1-$ \\
\hline Pisum sativum $\mathrm{L}$. & $0 / 0$ & $(+) /-$ \\
\hline Vicia faba $\mathrm{L}$. & $0 / 0$ & $(+) /-$ \\
\hline Vigna sinensis (Endl.) L. & $0 / 0$ & $-1-$ \\
\hline \multicolumn{3}{|l|}{ Lamiaceae } \\
\hline Ocimum basilicum $\mathrm{L}$. & $0 / 0$ & $+++/-$ \\
\hline Salvia splendens Sellow. & $0 / 0$ & $-1-$ \\
\hline \multicolumn{3}{|l|}{ Malvaceae } \\
\hline Gossypium hirsutum L. & $0 / 0$ & $++/-$ \\
\hline Hibiscus esculentus L. & $0 / 0$ & $+++/-$ \\
\hline H. sabdariffa $\mathrm{L}$. & $0 / 0$ & $+++/-$ \\
\hline Lavatera trimestris $\mathrm{L}$. & $0 / 0$ & $+/-$ \\
\hline \multicolumn{3}{|l|}{ Ranunculaceae } \\
\hline Ranunculus sardous Crantz & $0 / 0$ & $+1-$ \\
\hline \multicolumn{3}{|l|}{ Scrophulariaceae } \\
\hline Torenia fournieri Lind. & $0 / 0$ & $+1-$ \\
\hline \multicolumn{3}{|l|}{ Solanaceae } \\
\hline Capsicum aпnum $\mathrm{L}$. & $0 / 0$ & $-1-$ \\
\hline Lycopersicon esculentum Mill. & $0 / 0$ & $-1-$ \\
\hline Nicotiana benthamiana & $0 / 0$ & $+/-$ \\
\hline N. clevelandii A. Gray & $0 / 0$ & $(+) /-$ \\
\hline N. glutinosa L. & $0 / 0$ & $+++/-$ \\
\hline N. tabacum L. 'Xanthi' & $0 / 0$ & $-1-$ \\
\hline Solanum melongena $\mathrm{L}$. & $0 / 0$ & $+/-$ \\
\hline Petunia $\times$ hybrida Hort. & $0 / 0$ & $-1-$ \\
\hline
\end{tabular}

${ }^{\mathrm{a}} \mathrm{L} / \mathrm{S}=$ local$/$ systemic reaction.

${ }^{\mathrm{b}}$ Double antibody sandwich enzyme-linked immunosorbent assay.

c $0=$ no symptoms, $\mathrm{nll}=$ necrotic local lesions, $\mathrm{M}=$ mosaic, $\mathrm{B}=$ blisters, $\mathrm{Y}=$ yellowing, $\mathrm{VC}=$ vein clearing.

${ }^{\mathrm{d}}$ Serological reactivity measured in DAS-ELISA as the absorbance $(A)$ at $405 \mathrm{~nm}:-=A<0.05 ;+=$ $0.05<A<0.3 ;++=0.3<A<1 ;+++=A>1 ;(+)=0.05<A<0.3$ in some samples. Healthy plant extracts had $A$ ranging from 0.00 to 0.02 . Plants were considered infected when $A>2.5$ times the mean $A$ of the healthy controls.

tested. Seed transmission rates were $0.85 \%$ (nine infected plants out of 1,058 seedlings) in Charentais type and $3.78 \%(24$ out of 635) in snake cucumber type.

To characterize the mechanisms of seed transmission, seeds from the snake cucumber seed lots with the higher transmission rates were pooled and subjected to further experiments.

Seed dissection showed that the viral antigen is detected by DAS-ELISA in the seed coat, papery layer, and embryo (Table 2). However, mechanical inoculations detected infectious virions only in four embryo extracts that also gave high DASELISA readings.

External seed disinfection using the two methods described did not prevent seed transmission. Transmission rates observed for seeds disinfected with $\mathrm{HCl}$ or $\mathrm{Na}_{3} \mathrm{PO}_{4}$, and nontreated seeds were 16.1, 19.7, and $16.7 \%$, respectively (mean of three experiments, each with 30 seedlings per treatment). However, after disinfection, MRMV antigen was detected in fewer seed coats (Table 2).

Screening for resistance. Only two melon accessions, Jacumba and WMR29 (3), both of American cantaloupe type, out of the 367 accessions tested had some plants that did not develop symptoms and in which systemic infections were not detected in DAS-ELISA. When inoculations were conducted on larger numbers of plants, 81 Jacumba plants out of 114 and 50 WMR29 out of 133 did not show symptoms, while 150 out of 150 Védrantais plants developed severe mosaic and blister symptoms. In Jacumba and WMR29, infected plants developed symptoms ranging from leaf and stem necrosis to mosaic and blisters.

\section{DISCUSSION}

The isolate of MRMV from Sudan is similar to the type strain described in Yemen (9). The two isolates are closely related serologically, if not identical. Their host ranges are limited to cucurbits, but the Yemen isolate was able to induce systemic infection in Cucurbita sp. while the Sudan isolate was not. A similar difference in host range was observed for wild cucumber mosaic virus (WCuMV), another tymovirus infecting cucurbits but not related to MRMV (9). An Oregon isolate of WCuMV was found to infect cucumber, while California isolates did not (2). However, the symptoms induced in melon and watermelon by the MRMV isolate from Sudan were very similar to those described for the Yemen isolate $(9,20)$.

Cytopathological studies revealed in infected melons chloroplast alterations such as swollen shape, peripheral vesicles, and clumping, which are typical features for tymovirus infections $(13,16,17)$. These modified chloroplasts were reported to be involved in viral RNA synthesis in the peripheral vesicles, and in virion assembly 
in the cytoplasm close to these vesicles $(8,13)$.

Accumulated virus particles sometimes formed crystalline arrays of both nucleo- proteins and empty particles $(7,13)$. Such virion arrangements were observed with older infections, in the cytoplasm or vacuoles of parenchyma cells or in xylem cells, but not in the nucleus as reported for some tymoviruses $(7,13,16)$. However, severe alterations were generally observed in the nucleus with large electron-lucent zones.
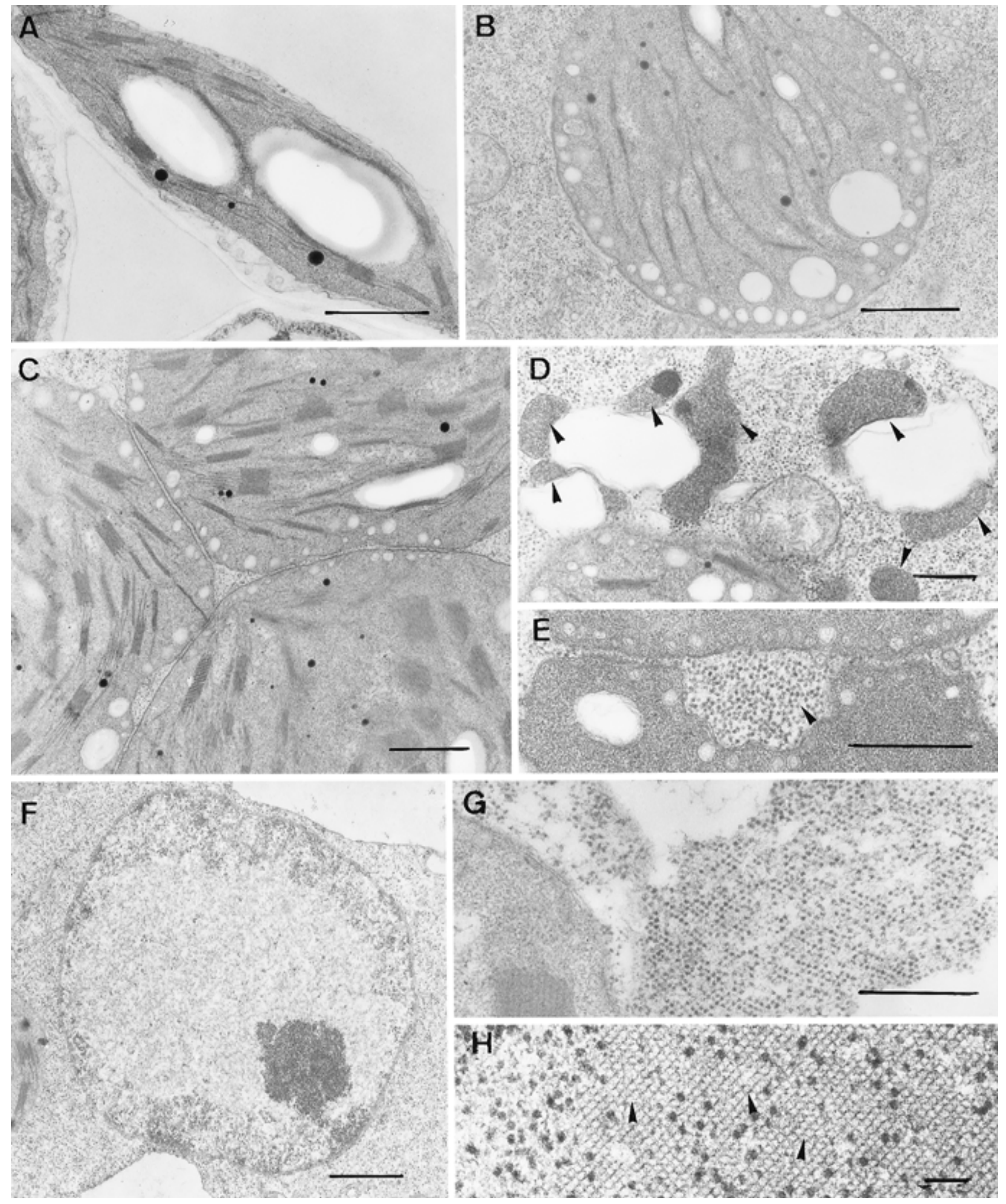

Fig. 3. Cytopathological effect of melon rugose mosaic virus (MRMV) in infected melon cells (B to H). (A) Typical lens-shaped chloroplast from a healthy plant, bordered by a regular double-membrane that presents no invaginations or vesicles; (B) swollen chloroplast with peripheral vesicles; (C) clump of swollen and vesiculated chloroplasts; (D) cytoplasm region containing numerous peroxisomes (indicated by arrows); (E) virion pocket (arrow) enclosed between two vesiculated chloroplasts; (F) typical nucleus with an enlarged area containing electron-lucent material; (G) crystalline array of viral particles protruding into the vacuole of a mesophyll cell; and $\mathbf{( H )}$ crystalline array of empty particles (arrows) in a xylem tube. Note the presence of a few complete virus particles with electron dense nucleoproteins. Scale bars represent $1 \mu \mathrm{m}$ for A, B, C, and F; $0.5 \mu \mathrm{m}$ for D, E, and G; and $0.1 \mu \mathrm{m}$ for $\mathrm{H}$. 
Table 2. Detection by double antibody sandwich enzyme-linked immunosorbent assay (DAS-ELISA) of melon rugose mosaic virus in different parts of snake cucumber seeds

\begin{tabular}{lccc}
\hline & & Seed parts & \\
\cline { 2 - 4 } Seed lot & Seed coat & Papery layer & Embryo \\
\hline Infected & $7 / 20^{\mathrm{a}}$ & $10 / 20$ & $7 / 20$ \\
& $(0.17->2)^{\mathrm{b}}$ & $(0.11-0.63)$ & $(0.27->2)$ \\
Disinfected $(\mathrm{HCl})^{\mathrm{c}}$ & $1 / 20$ & $8 / 20$ & $8 / 20$ \\
& $(0.12)$ & $(0.11-0.35)$ & $(0.66->2)$ \\
Disinfected $\left(\mathrm{Na}_{3} \mathrm{PO}_{4}\right)^{\mathrm{d}}$ & $1 / 20$ & $4 / 20$ & $6 / 20$ \\
& $(0.17)$ & $(0.12-0.37)$ & $(0.2->2)$ \\
Healthy & $0 / 10$ & $0 / 10$ & $0 / 10$ \\
& $(0.00-0.03)^{\mathrm{e}}$ & $(0.00-0.02)$ & $(0.00-0.04)$ \\
\hline
\end{tabular}

a Number of samples positive in DAS-ELISA over the numbers of sample tested.

b Range of absorbance $(A)$ at $405 \mathrm{~nm}$ of the samples rated as positive in DAS-ELISA.

c Seeds were immersed in $0.1 \mathrm{~N} \mathrm{HCl}$ for $30 \mathrm{~min}$ then rinsed and dried.

${ }^{d}$ Seeds were immersed in $10 \% \mathrm{Na}_{3} \mathrm{PO}_{4}, 0.5 \%$ sodium dodecyl sulfate (SDS), $0.5 \%$ Tween 20 , and $2 \%$ sodium hypochlorite for $30 \mathrm{~min}$, then rinsed and dried.

e Range of absorbance at $405 \mathrm{~nm}$ of the healthy controls. Extracts were considered positive when $A>$ 2.5 times the mean $A$ of the healthy controls.

The synthesis of complete nucleoproteins and empty shells, which were observed in thin sections as well as in leaf extracts or purified preparations, is another characteristic feature of tymoviruses $(12,13)$. This provides further evidence that MRMV is a member of the tymoviruses, as suggested by Jones et al. (1986) (9).

True seed transmission has been reported for a few tymoviruses, such as Andean potato latent virus (11), but this is not a common feature for other members of this genus (12) and was not reported for MRMV. MRMV seed transmission was demonstrated in Charentais melon type and in snake cucumber type. Infectious virus particles were present in the embryo, since they were detected by mechanical transmission assays. Antigen was also detected in the seed coat and papery layers, but it is not known whether the virions are infective but at low concentrations, or inactivated in these tissues. Seed disinfection treatments did not prevent seed transmission, suggesting an internal transmission of the virus.

Seed transmission may be responsible for the spread of MRMV in the Red Sea region. In Yemen, MRMV was found to occur quite frequently in different parts of the country $(1,10)$. A preliminary survey of cucurbit viruses in Sudan (14), confirmed by further observations, indicated that MRMV is present only in Kassala and Gash delta regions, both located next to the Red Sea. Because of MRMV seed transmission, a special care should be taken when evaluating and transferring cucurbit germ plasm from this region or from Yemen.
Several tymoviruses are transmitted by beetles (12,13). Beetles (including $\mathrm{He}$ nosepilachna elaterii (Rossi) and Aulacophora foveicollis (Lucas)) are very common in cucurbits in the Kassala region. They could be MRMV vectors in the fields. MRMV was also found to be transmitted by leaf contact (data not shown); this could also contribute to virus dissemination once the virus is introduced into the field through infected seeds.

Resistant plants were found in two melon accessions, although in both cases, plants were segregating for this character. A selfing program is in progress to obtain homozygous resistant lines. These lines could be used in breeding programs if the virus were to cause more severe epidemics.

\section{ACKNOWLEDGMENTS}

We thank P. Jones for providing MRMV antiserum and MRMV dried culture, C. Desbiez for her help during this work, and J. Rougier for the photographs.

\section{LITERATURE CITED}

1. Alhubaishi, A. A., Walkey, D. G. A., Webb, M. J. W., Bolland, C. J., and Cook, A. A. 1987. A survey of horticultural plant virus diseases in the Yemen Arab Republic. FAO Plant Prot. Bull. 35:135-143.

2. Allen, T. C., and Fernald, K. 1971. Recovery and partial characterization of wild cucumber mosaic virus from Marah oreganus. Plant Dis. Rep. 55:546-550.

3. Bohn, G. W., Kishaba, A. N., and McCreight, J. D. 1980. WMR29 muskmelon breeding line. HortScience 15:539-540.

4. Campbell, R. N., Wipf-Scheibel, C., and Lecoq, H. 1996. Vector assisted seed transmission of melon necrotic spot virus in melons. Phytopathology 86:1294-1298.
5. Clark, M. F., and Adams, A. M. 1977. Characterization of a microplate method of enzyme linked immunosorbent assay for the detection of plant viruses. J. Gen. Virol 34:475-483.

6. Delécolle, B. 1978. Essais de rationalisation des méthodes de préparation d'échantillons végétaux pour la microscopie électronique : problème des précipités parasites. Cell. Mol. Biol. 23:431-436.

7. Hatta, T. 1976. Recognition and measurement of small isometric virus particles in thin sections. Virology 69:237-245.

8. Hatta, T., and Matthews, R. E. F. 1976. Sites of coat protein accumulation in turnip yellow mosaic infected cells. Virology 73:1-16.

9. Jones, P., Ba Angood, S., and Carpenter, J. M. 1986. Melon rugose mosaic virus, the cause of a disease of watermelon and sweetmelon. Ann. Appl. Biol. 108:303-307.

10. Jones, P., Sattar, M. H. A., and Al Kaff, N. 1988. The incidence of virus disease in watermelon and sweetmelon crops in the People Democratic Republic of Yemen and its impact on cropping policy. Asp. Appl. Biol. 17:203207.

11. Jones, R. A. C., and Fribourg, C. E. 1977. Beetle, contact and true seed transmission of andean potato latent virus. Ann. Appl. Biol. $86: 123-128$.

12. Koenig, R., and Lesemann, D. E. 1979. Tymovirus group. Commonw. Mycol. Inst./Assoc. Appl. Biol. Description of Plant Viruses No. 214.

13. Koenig, R., and Lesemann, D. E. 1981. Tymovirus. Pages 33-60 in: Handbook of Plant Virus Infections and Comparative Diagnosis. E. Kurstak, ed. Elsevier North Holland, Amsterdam.

14. Lecoq, H., Dafalla, G. A., Mohamed, Y. F., Ali, H. M., Wipf-Scheibel, C., Desbiez, C., ElJack, A. R., Omara, S. K., and Pitrat, M. 1994. Survey of virus diseases infecting cucurbit crops in eastern, central and western Sudan. Univ. Khartoum J. Agric. Sci. 2:6782.

15. Lecoq, H., and Pitrat, M. 1985. Specificity of the helper-component-mediated aphid transmission of three potyviruses infecting muskmelon. Phytopathology 75:890-893.

16. Lesemann, D. E. 1977. Virus group specific and virus specific cytological alterations induced by members of tymovirus group. Phytopathol. Z. 90:315-336.

17. Martelli, G. P., and Russo, M. 1984. Use of thin sectioning for visualization and identification of plant viruses. Methods Virol. 8:143224.

18. Matthews, R. E. F. 1980. Turnip yellow mosaic virus. Commonw. Mycol. Inst./Assoc. Appl. Biol. Description of Plant Viruses No. 230.

19. Nolan, P. A., and Campbell, R. N. 1984 Squash mosaic virus detection in individual seeds and seed lots of cucurbits by enzymelinked immunosorbent assay. Plant Dis. 68:971-975.

20. Walkey, D. G. A. 1992. Plant virus diseases of Yemen and associated areas. Overseas Development Administration, London. 